International Journal of Food Science, Nutrition and Dietetics (IJFS)

ISSN 2326-3350

\title{
Measurement Of Activity Concentrations Of 226Ra, 232Th, 40K And 137Cs In Some Common Spices Consumed By Inhabitants In Accra Metropolis, Ghana.
}

C. Kansaana ${ }^{1 *}$, E. O. Darko ${ }^{1}$, O. K. Adukpo ${ }^{1}$, A. Faanu ${ }^{1}$, E. Shitsi ${ }^{2}$, N.S. Opata ${ }^{2}$, L. Tettey-Larbi ${ }^{1}$

Research Article

${ }^{*}$ Radiation Protection Institute, Ghana Atomic Energy Commission, Box LG 80, Legon, Ghana.

${ }^{2}$ National Nuclear Research Institute, Ghana Atomic Energy Commission, Box LG 80, Legon, Ghana.

\section{Abstract}

A spice is a vegetable substance of indigenous or exotic origin which is or has a hot, pigment taste, used to enhance taste of foods or to add to them the stimulant ingredients contained in them. Knowledge of radioactivity levels in human diet is of particular concern for the estimation of possible radiological hazards to human health. In this study, the radioactivity concentrations of ${ }^{226} \mathrm{Ra}$, ${ }^{232} \mathrm{Th}$, ${ }^{40} \mathrm{~K}$ and ${ }^{137} \mathrm{Cs}$ in some selected natural and processed spices of different brands in the Madina District of Accra Metropolis were determined and the ingested doses via food consumption were also assessed using gamma spectrometry. The average activity concentration of ${ }^{226} \mathrm{Ra}$, ${ }^{232} \mathrm{Th}$, ${ }^{40} \mathrm{~K}$ and ${ }^{137} \mathrm{Cs}$ in the natural spices were $0.81 \pm 0.2 \mathrm{BqKg}^{-1}, 0.98 \pm 0.4 \mathrm{BqKg}^{-1}, 2.19 \pm 0.9 \mathrm{BqKg}^{-1}$ and $0.06 \pm 0.01 \mathrm{BqKg}^{-1}$ respectively. For the processed spices, the average activity concentration of ${ }^{226} \mathrm{Ra},{ }^{232} \mathrm{Th},{ }^{40} \mathrm{~K}$ and ${ }^{137} \mathrm{Cs}$ were $0.18 \pm 0.1 \mathrm{BqKg}^{-1}, 0.3 \pm 0.1 \mathrm{BqKg}^{-1}, 1.3 \pm 0.8 \mathrm{BqKg}^{-1}$ and $0.02 \pm 0.01 \mathrm{BqKg}^{-1}$ respectively. The levels of ${ }^{137} \mathrm{Cs}$ observed in the samples are within the range of 'background' concentrations. The estimated total annual effective dose received from ${ }^{226} \mathrm{Ra}$, ${ }^{232} \mathrm{Th}$ and ${ }^{137} \mathrm{Cs}$, due to consumption of natural (fresh) and processed spices by the inhabitants of Madina in the Accra metropolis was $8.47 \mu \mathrm{Svy}^{-1}$ and this is far below the average radiation dose of $0.29 \mathrm{mSvy}^{-1}$ received per caput worldwide due to ingestion of natural radionuclides provided in UNSCEAR (2000) report. The results indicate insignificant radiological health hazard to the public due to the consumption of spices via foods.

Key Words: ${ }^{226} \mathrm{Ra} ;{ }^{232} \mathrm{Th} ;{ }^{40} \mathrm{~K} ;{ }^{137} \mathrm{Cs}$; Spices; Hpge; Effective Dose.

\section{*Corresponding Author:}

Charles Kansaana

Radiation Protection Institute,

Ghana Atomic Energy Commission,

Box LG 80, Legon, Ghana.

Tel: +233245117033

E-mail: kansaana@yahoo.com

Received: October 16, 2013

Accepted: November 20, 2013

Published: December 02, 2013

Citation: C. Kansaana, et al (2013) Measurement of Activity Concentrations of ${ }^{226} \mathrm{Ra},{ }^{232} \mathrm{Th},{ }^{40} \mathrm{~K}$ and ${ }^{137} \mathrm{Cs}$ in Some Common Spices Consumed By Inhabitants in Accra Metropolis, Ghana. Int J Food Sci Nutr Diet. 2(8), 75-80. doi: http://dx.doi.org/10.19070/2326-3350-1300014

Copyright: Charles Kansaana. ${ }^{\circ} 2013$ This is an open-access article distributed under the terms of the Creative Commons Attribution License, which permits unrestricted use, distribution and reproduction in any medium, provided the original author and source are credited.

\section{Introduction}

Humans are continuously exposed to ionizing radiation of natural sources (NORMS) from terrestrial and extraterrestrial origin, and artificial sources used for various applications in medicine, agriculture, industry, research and teaching. The extent of exposure if significant could lead to detrimental health effects. Exposure to high levels above background radiation could lead to somatic and genetic effects that tend to damage critical and/or radiosensitive organs of the body, which ultimately can lead to death[1].

A spice is a dried seed, fruit, root, bark, or vegetative substance primarily used for flavouring, colouring or preserving food and can sometimes be used to hide other flavours. It is sometimes used as a preservative by killing or preventing the growth of harmful bacteria. Spices are distinguished from herbs, which are parts of leafy green plants also used for flavouring or as garnish. Many spices have antimicrobial properties and may explain why spices are more commonly used in warmer climates, which have more infectious disease, and why use of spices is especially prominent in meat, which is particularly susceptible to spoiling [2]. There are two groups of spices consumed by Ghanaians and they are the natural or the fresh ones and those that have been processed into powdered or solid forms. Some people prefer the processed ones to the fresh ones. This could be due to storage or convenience.

Assessment of contamination of spices consume by the population is very important to know the baseline value, or the level of radiation dose of both natural and artificial radionuclides received by them. Knowledge of the concentrations and distributions of the radionuclides in spices are of interest since it provides useful information in the monitoring of environmental radioactivity. Studies on the natural and artificial radioactivity levels in spices via foods assume importance as it is necessary to estimate the ingestion dose to the public. However, in Ghana no study has been performed to determine the radionuclides concentrations in spices and the dose assessment from consumption of these spices by the Ghanaian population.

In this study, the radioactivity levels of ${ }^{226} \mathrm{Ra},{ }^{232} \mathrm{Th}$ and ${ }^{40} \mathrm{~K}$ and the artificial radionuclide ${ }^{137} \mathrm{Cs}$ in fresh and processed spices were determined using gamma spectrometry. The assessment of the ingested dose in these radionuclides via food consumption was also made. The natural spices considered in the study were Onion, Garlic, Ginger, Ashanti Pepper, and Green Pepper and the processed spices were Adja, Benny, Maggi, Mamita, Jumbo, Napa Valley, Onga, Royco, Mimido, and Gino Curry Powder. The study focused on these spices because they are commonly available and 
used in Ghana. These spices were purchased from different traders at the Madina market in the Accra Metropolis of Ghana. This study, therefore, investigated the extent of the exposure of the general public due to intake of spices as part of the national effort to establish baseline values for the Regulatory Authorities to control the exposure of the public to natural and artificial radionuclides due to the consumption of spices in Ghana.

\section{Material and Methods}

\section{Background of the Study Area}

Accra is the capital and the largest city in Ghana, with an estimated urban population of 2,291,352 as of 2012. Accra is also the capital of the Greater Accra Region and of the Accra Metropolitan District. Accra lies between longitudes $0^{\circ} 12^{\prime} 00^{\prime \prime} \mathrm{W}$ and $0.2^{\circ} \mathrm{W}$ and latitudes $5^{\circ} 33^{\prime} 00^{\prime \prime} \mathrm{N}$ and $5.55^{\circ} \mathrm{N}$ [3].

Accra stretches along the Ghanaian Atlantic coast and extends north into the country's interior. It is Ghana's primate city, serving as the nation's economic and administrative hub. It is furthermore a centre of culture and tourism, sporting a wide range of nightclubs, restaurants and hotels.

The central business district of Accra contains the city's main banks and department stores, the Cocoa Marketing Board headquarters (dealing with cocoa, Ghana's chief export), and an area known as the Ministries, where Ghana's government administration is concentrated. Economic activities in Accra include the financial and agricultural sectors, Atlantic fishing, and the manufacture of processed food, lumber, plywood, textiles, clothing and chemicals.

Accra lies within the coastal-savanna zone with low annual rainfall. The rainfall pattern of the city is bimodal with the major season falling between the months of March and June, and a mi- nor rainy season from September to October. The mean annual rainfall is about $730 \mathrm{~mm}$. Mean temperatures vary from $24^{\circ} \mathrm{C}$ in August to $27^{\circ} \mathrm{C}$ in March [4].

\section{Geography of the Madina Markets}

There are about 47 market sites in Accra, the majority of which operate during the day and a few operate at night. Most of the markets are located in the old town section of Accra but were intended to be eventually distributed in Accra's different residential neighborhoods.

Madina is a town in the Ga East Municipal district, a district in the Greater Accra Region of southeastern Ghana. It lies between longitudes $0^{\circ} 10^{\prime} 0^{\prime \prime} \mathrm{W}$ and latitudes $5^{\circ} 41^{\prime} 0^{\prime \prime} \mathrm{N}$ and is next to the University of Ghana. Madina is the twelfth most populous settlement in Ghana, in terms of population, with a population of 137,162 people. The Madina market is one of the largest markets in Accra metropolis and all walks of life come to Madina to shop. The market relies on the importation of spices from foreign countries and those locally produced. Figure 1 shows the map of Greater Accra region, Ghana, showing the study area, Madina in the Ga East Municipal district [5].

\section{Sampling and sample preparation}

A total of fifteen samples were purchased from different traders at the Madina market. They included five natural spices namely Onion, Garlic, Ginger, Ashanti Pepper, and Green Pepper and ten processed spices of different brands namely Adja, Benny, Maggi, Mamita, Jumbo, Napa Valley, Onga, Royco, Mimido, and Gino Curry Powder. The natural samples were washed, peeled when necessary, and oven dried at a temperature of $105^{\circ} \mathrm{C}$ and then ground into powder form for analysis. The prepared samples were then measured in 1.0 1 Marinelli beakers, i.e. in the same ge- 
ometry as the standard. The prepared samples were stored in the laboratory prior to analysis.

\section{Instrumentation and calibration}

Instrumental analysis without pre-treatment (non-destructive) was used for the measurement of gamma rays for the samples using a High Purity Germanium detector (HPGE). The relative efficiency of the detector is $25 \%$ with energy resolution of 1.8 $\mathrm{keV}$ at gamma ray energy of $1332 \mathrm{keV}$ of ${ }^{60} \mathrm{Co}$. The identification of individual radionuclides was performed using their gamma ray energies and the quantitative analysis of radionuclides was performed using gamma ray spectrum analysis software, ORTEC MAESTRO-32.

The detector is mounted in a cylindrical lead shield $(100 \mathrm{~mm})$ lined with copper, cadmium and plexiglass ( $3 \mathrm{~mm}$ each) to reduce the background radiation. The detector is cooled in liquid nitrogen at a temperature of $-196{ }^{\circ} \mathrm{C}(77 \mathrm{k})$. In order to determine the background distribution in the environment around the detector, ten empty Marinelli beakers were thoroughly cleaned and filled with distilled water and counted for $36000 \mathrm{~s}$ in the same geometry as the samples. The background spectra were used to correct the net peak area of gamma rays of measured isotopes. The background spectra were also used to determine the minimum detectable activities of the measured natural radionuclides and the results are presented in Table 1 .

The efficiency calibrations were carried out by counting standard radionuclides of known activities with well-defined energies in the energy range of $60 \mathrm{keV}$ to $\sim 2000 \mathrm{keV}$. For the analysis of samples, the efficiency calibration was carried out using standard radionuclides uniformly distributed in solid water with volume and density of $1000 \mathrm{ml}$ and $1.0 \mathrm{gm}^{-3}$ respectively (source number: NW146 and manufactured by QSA Global GmbH).

\section{Calculation of activity concentrations from spectral data}

A counting time of 36,000 seconds was used to acquire spectral data for each sample and the data were evaluated. The background spectra were measured frequently under the same conditions of sample measurements and were used to correct the calculated sample activities [6]. The characteristic gamma peaks selected for the determination of the different radionuclides were $295 \mathrm{keV}$ for the ${ }^{226} \mathrm{Ra}\left({ }^{214} \mathrm{~Pb}\right), 352 \mathrm{keV}$ for the ${ }^{226} \mathrm{Ra}\left({ }^{214} \mathrm{~Pb}\right), 609 \mathrm{keV}$ for the ${ }^{226} \mathrm{Ra}\left({ }^{14} \mathrm{Bi}\right), 911,969$ and $338 \mathrm{keV}$ for the ${ }^{232} \mathrm{Th}\left({ }^{228} \mathrm{Ac}\right), 662 \mathrm{keV}$ for the ${ }^{137} \mathrm{Cs}$ and $1461 \mathrm{keV}$ for the ${ }^{40} \mathrm{~K}$.

The analytical expression used in the calculation of the activity concentrations in $\mathrm{Bq} / \mathrm{Kg}$ for the samples is as shown in equation

$A \_a c=\left(N \_s a m \exp \left(\lambda T \_d\right)\right) /\left(P \_E *(E) * T \_c * M\right)$

where; $A_{\text {ac }}$ is the activity concentration, $\lambda$ is the decay constant, $\mathrm{N}_{\text {sam }}$ is total net counts for the sample in the peak range, $\mathrm{P}_{\mathrm{E}}$ is the gamma-ray emission probability, $\mathrm{T}_{\mathrm{d}}$ is decay time between the sampling and counting, $\mathrm{T}_{\mathrm{c}}$ is the counting time, $\varepsilon(\mathrm{E})$ is the total counting efficiency of the detector system, $M$ is the mass of sample $(\mathrm{kg})$ and the expression $\exp \left(\lambda \mathrm{T}_{\mathrm{d}}\right)$ is the correction factor for decay between sampling and counting [7].

\section{Estimation of Uncertainty}

In this study, the uncertainty associated with the determination of activity concentrations of each radionuclide was estimated using equation 2 .

$$
A \_a c=N /\left(P \_E * \varepsilon(E) * T \_c * M\right)
$$

where $\mathrm{A}_{\mathrm{ac}}$ is the activity concentration in $\mathrm{Bqkg}^{-1}, \mathrm{~N}$ is the background corrected net peak area, $\varepsilon(\mathrm{E})$ is the absolute detector efficiency, $\mathrm{P}_{\mathrm{E}}$ is the gamma yield, $\mathrm{T}_{\mathrm{c}}$ is the counting time of the sample, $\mathrm{M}$ is the mass of the sample in $\mathrm{kg}$.

Neglecting the uncertainties in the counting time and the gamma emission probability, the following expression was used to determine the overall uncertainty in the activity.

$$
\text { dA_ac }=A \_a c\left\{(d N / N)^{\wedge} 2+(d \varepsilon / \varepsilon)^{\wedge} 2+(d M / M)^{\wedge} 2\right\}^{\wedge 1 / 2}
$$

where; $\mathrm{dN}$ is determined from the uncertainty in the integration

Table 1: Minimum Detectable Activity (MDA) of the gamma counting system 
of the peak area of each full energy event; $\mathrm{dM}$ is the standard uncertainty on the weighing balance used to weigh the samples and the standard uncertainty was quoted to be $0.1 \mathrm{mg}$; d $\varepsilon$ is the uncertainty in the efficiency.

\section{Results and Discussions}

\section{Activity concentrations in samples}

Table 2 shows the results of the measured activity concentrations of ${ }^{226} \mathrm{Ra},{ }^{232} \mathrm{Th},{ }^{40} \mathrm{~K}$ and ${ }^{137} \mathrm{Cs}$ via their daughters in the five natural spices purchased from the Madina market in the Accra Metropolis of Ghana.

The activity concentration of ${ }^{226} \mathrm{Ra}$ in the natural spices analyzed ranged from $0.35 \pm 0.2$ to $1.19 \pm 0.1 \mathrm{~Bq} / \mathrm{Kg}$ with an average value of $0.81 \pm 0.2 \mathrm{~Bq} / \mathrm{Kg}$. The minimum and maximum activity concentrations were obtained from garlic and ginger respectively. For ${ }^{232} \mathrm{Th}$, the radionuclide concentrations in the spices ranged from $0.62 \pm 0.3$ to $1.02 \pm 0.6 \mathrm{~Bq} / \mathrm{Kg}$ with an average value of 0.98 $\pm 0.4 \mathrm{~Bq} / \mathrm{Kg}$. The minimum activity concentration of ${ }^{232} \mathrm{Th}$ was recorded from green pepper whilst the maximum was obtained from onion. The radionuclide concentrations of ${ }^{40} \mathrm{~K}$ also ranged from $1.92 \pm 0.7$ to $2.42 \pm 0.8 \mathrm{~Bq} / \mathrm{Kg}$ with an average value of $2.28 \pm 0.9 \mathrm{~Bq} / \mathrm{Kg}$. The lowest activity concentration of ${ }^{40} \mathrm{~K}$ was recorded from green pepper whilst the highest was obtained from ginger.

Caesium-137 $\left({ }^{137} \mathrm{Cs}\right)$ was the only artificial radionuclide that was detected in the spices. The activity concentrations of ${ }^{137} \mathrm{Cs}$ varied in a range of $0.04 \pm 0.01$ to $0.08 \pm 0.02 \mathrm{~Bq} / \mathrm{Kg}$ with an average of $0.06 \pm 0.01 \mathrm{~Bq} / \mathrm{Kg}$. The minimum and the maximum concentrations of ${ }^{137} \mathrm{Cs}$ were obtained from green pepper and ginger respectively.

Table 3 also shows the results of the measured activity concentrations of ${ }^{226} \mathrm{Ra},{ }^{232} \mathrm{Th},{ }^{40} \mathrm{~K}$ and ${ }^{137} \mathrm{Cs}$ via their daughters in the ten processed spices of different brands.

The average value of the activity concentration of ${ }^{226} \mathrm{Ra}$ is 0.18 $\pm 0.1 \mathrm{~Bq} / \mathrm{Kg}$ in a range of $0.14 \pm 0.1$ to $0.55 \pm 0.3 \mathrm{~Bq} / \mathrm{Kg}$. The minimum and maximum activity concentrations were obtained from jumbo and rocyo respectively. For ${ }^{232} \mathrm{Th}$, the average activity concentration was $0.3 \pm 0.1 \mathrm{~Bq} / \mathrm{Kg}$ in a range of $0.18 \pm 0.1$ to $0.68 \pm 0.3 \mathrm{~Bq} / \mathrm{Kg}$. The minimum activity concentration of ${ }^{232} \mathrm{Th}$ was recorded from benny whilst the maximum was obtained from mamita. The average activity concentration of ${ }^{40} \mathrm{~K}$ was 1.30 \pm 0.8 in a range of $0.95 \pm 0.4$ to $1.72 \pm 0.7 \mathrm{~Bq} / \mathrm{Kg}$ with maggi and rocyo recording the lowest and highest activity concentration respectively.

The concentration of ${ }^{137} \mathrm{Cs}$ in most of the processed spices was below the MDA, except in 4 samples with an average value of $0.02 \pm 0.01 \mathrm{~Bq} / \mathrm{Kg}$ in a range of 0.02 to $0.04 \mathrm{~Bq} / \mathrm{Kg}$. The lowest and highest activity concentrations of ${ }^{137} \mathrm{Cs}$ were found in onga and napa valley respectively. The exemptions level of ${ }^{137} \mathrm{Cs}$ in any material as recommended in the BSS [8] is $10 \mathrm{~Bq} / \mathrm{Kg}$. The activity concentrations of ${ }^{137} \mathrm{Cs}$ in all the samples studied are below the exemption levels.

The measured activity concentrations in each radionuclide in the natural spices were found to be higher than the processed spices. The extra use of phosphate fertilizer in soil can be a factor causing the increase in the radionuclide concentration in the natural spices than the processed ones [9]. Some surveys conducted have also shown that these processed spices are sometimes adulterated with other substances just to increase the quantity. The presence of some foreign substances such as sand from the environment or method of drying or milling has also been reported [10].

\section{Estimation of internal dose from ingested spices via foods}

The intake of radionuclides in spices through the food chain is dependent on the concentration of radionuclides in the various spices and on the food consumption. It is obvious that the consumption of spices via food depends on many factors, some of which concern the individual while others are group related. Information on the range and amounts of spices consumed regularly by individuals is required. The risk associated with an intake of radionuclides in the body is proportional to the total dose delivered by the radionuclides while staying in the various organs.

In general, it is assumed that stochastic effects occur linearly with dose and usually the effective dose (E) is used to define this risk. The annual effective dose, $\mathrm{E}(\mathrm{mSv} / \mathrm{y})$ to an adult individual due to intake of natural radionuclides in the spices via food was calculated on the basis of the activity concentrations of the radionuclides. The annual effective dose owing to ingestion of ${ }^{226} \mathrm{Ra},{ }^{232} \mathrm{Th}$ and ${ }^{137} \mathrm{Cs}$ in the spices was calculated using equation 1.

$$
\mathrm{E}=\Sigma\left(\mathrm{A}_{\mathrm{s}} \times \mathrm{I}_{\mathrm{s}} \times \mathrm{DCF}_{\mathrm{s}}\right)
$$

\section{MDA: Minimum Detectable Activity}

Table 2: Activity concentrations of radionuclides measured in natural spices from Madina market in Accra Metropolis of Ghana ( \pm Uncertainty).

\begin{tabular}{|c|c|c|c|c|c|c|c|c|c|}
\hline \multirow{3}{*}{$\begin{array}{c}\text { Name of } \\
\text { Spices }\end{array}$} & \multicolumn{4}{|c|}{${ }^{226} \mathrm{Ra}\left(\mathrm{Bq} / \mathrm{Kg}_{\mathrm{fresh}}\right)$} & \multicolumn{3}{|c|}{${ }^{232} \mathrm{Th}\left(\mathrm{Bq} / \mathrm{Kg}_{\mathrm{fresh}}\right)$} & \multirow{3}{*}{$\begin{array}{c}{ }^{{ }^{40} \mathrm{~K}} \\
(\mathrm{~Bq} / \mathrm{Kg})\end{array}$} & \multirow{3}{*}{$\begin{array}{c}\begin{array}{c}{ }^{137} \mathrm{Cs} \\
(\mathrm{Bq} / \mathrm{Kg})\end{array} \\
\begin{array}{c}662 \\
(\mathrm{keV})\end{array}\end{array}$} \\
\hline & ${ }^{214} \mathrm{~Pb}$ & ${ }^{214} \mathrm{~Pb}$ & ${ }^{214} \mathbf{B i}$ & ${ }^{214} \mathbf{B i}$ & ${ }^{228} \mathrm{Ac}$ & ${ }^{228} \mathrm{Ac}$ & ${ }^{228} \mathrm{Ac}$ & & \\
\hline & $\begin{array}{c}295.22 \\
(\mathrm{keV})\end{array}$ & $\begin{array}{c}351.93 \\
(\mathrm{keV})\end{array}$ & $\begin{array}{c}609.31 \\
(\mathrm{keV})\end{array}$ & $\begin{array}{c}1120.28 \\
(\mathrm{keV})\end{array}$ & $\begin{array}{l}911.20 \\
(\mathrm{keV})\end{array}$ & $\begin{array}{c}968.97 \\
(\mathrm{keV})\end{array}$ & $\begin{array}{c}338.32 \\
(\mathrm{keV})\end{array}$ & & \\
\hline Onion & $0.71 \pm 0.2$ & $0.60 \pm 0.2$ & $1.04 \pm 0.5$ & $<\mathrm{MDA}$ & $1.14 \pm 0.6$ & $1.20 \pm 0.7$ & $<\mathrm{MDA}$ & $2.35 \pm 0.8$ & $0.07 \pm 0.01$ \\
\hline Garlic & $0.68 \pm 0.2$ & $<\mathrm{MDA}$ & $<\mathrm{MDA}$ & $0.35 \pm 0.2$ & $<\mathrm{MDA}$ & $<\mathrm{MDA}$ & $<\mathrm{MDA}$ & $2.28 \pm 0.9$ & $0.06 \pm 0.01$ \\
\hline Ginger & $1.19 \pm 0.1$ & $0.85 \pm 0.5$ & $1.05 \pm 0.6$ & $<\mathrm{MDA}$ & $1.02 \pm 0.6$ & $<\mathrm{MDA}$ & $<\mathrm{MDA}$ & $2.42 \pm 0.8$ & $0.08 \pm 0.02$ \\
\hline Ashanti Pepper & $0.89 \pm 0.3$ & $<\mathrm{MDA}$ & $0.60 \pm 0.3$ & $0.56 \pm 0.3$ & $0.99 \pm 0.4$ & $0.62 \pm 0.3$ & $<\mathrm{MDA}$ & $1.98 \pm 0.6$ & $0.05 \pm 0.01$ \\
\hline Green Pepper & $1.10 \pm 0.4$ & $<\mathrm{MDA}$ & $<\mathrm{MDA}$ & $0.87 \pm 0.4$ & $0.89 \pm 0.4$ & $<\mathrm{MDA}$ & $<\mathrm{MDA}$ & $1.92 \pm 0.6$ & $0.04 \pm 0.01$ \\
\hline
\end{tabular}


MDA: Minimum Detectable Activity

Table 3: Activity concentrations of radionuclides measured in processed spices of different brands from Madina market in Accra Metropolis of Ghana ( \pm Uncertainty).

\begin{tabular}{|c|c|c|c|c|c|c|c|c|c|}
\hline \multirow{3}{*}{$\begin{array}{c}\text { Name of } \\
\text { Spices }\end{array}$} & \multicolumn{4}{|c|}{${ }^{226} \mathrm{Ra}(\mathrm{Bq} / \mathrm{kg}$ processed) } & \multicolumn{3}{|c|}{${ }^{232} \mathrm{Th}$ (Bq/kg processed) } & \multirow{3}{*}{$\begin{array}{c}{ }^{{ }^{40} \mathrm{~K}} \\
(\mathrm{~Bq} / \mathrm{kg})\end{array}$} & \multirow{3}{*}{$\begin{array}{c}\begin{array}{c}{ }^{137} \mathrm{Cs} \\
(\mathrm{Bq} / \mathrm{kg})\end{array} \\
662 \\
(\mathrm{keV})\end{array}$} \\
\hline & ${ }^{214} \mathbf{P b}$ & ${ }^{214} \mathbf{P b}$ & ${ }^{214} \mathrm{Bi}$ & ${ }^{214} \mathbf{B i}$ & ${ }^{228} \mathrm{Ac}$ & ${ }^{228} \mathrm{Ac}$ & ${ }^{228} \mathrm{Ac}$ & & \\
\hline & $\begin{array}{c}295.22 \\
(\mathrm{keV})\end{array}$ & $\begin{array}{c}351.93 \\
(\mathrm{keV})\end{array}$ & $\begin{array}{c}609.31 \\
(\mathrm{keV})\end{array}$ & $\begin{array}{c}1120.28 \\
(\mathrm{keV})\end{array}$ & $\begin{array}{l}911.20 \\
(\mathrm{keV})\end{array}$ & $\begin{array}{c}968.97 \\
(\mathrm{keV})\end{array}$ & $\begin{array}{c}338.32 \\
(\mathrm{keV})\end{array}$ & & \\
\hline Adja & $<\mathrm{MDA}$ & $<\mathrm{MDA}$ & $0.30 \pm 0.1$ & $0.55 \pm 0.2$ & $0.26 \pm 0.1$ & $0.34 \pm 0.1$ & $<\mathrm{MDA}$ & $1.36 \pm 0.6$ & $<\mathrm{MDA}$ \\
\hline Benny & $<\mathrm{MDA}$ & $<\mathrm{MDA}$ & $<\mathrm{MDA}$ & $0.34 \pm 0.2$ & $0.22 \pm 0.1$ & $0.18 \pm 0.1$ & $<\mathrm{MDA}$ & $1.67 \pm 0.7$ & $0.03 \pm 0.01$ \\
\hline Maggi & $0.17 \pm 0.1$ & $0.15 \pm 0.1$ & $<\mathrm{MDA}$ & $<\mathrm{MDA}$ & $0.34 \pm 0.1$ & $0.49 \pm 0.1$ & $<\mathrm{MDA}$ & $0.95 \pm 0.4$ & $<\mathrm{MDA}$ \\
\hline Mamita & $<\mathrm{MDA}$ & $<\mathrm{MDA}$ & $0.51 \pm 0.2$ & $0.55 \pm 0.3$ & $0.68 \pm 0.3$ & $0.42 \pm 0.1$ & $<\mathrm{MDA}$ & $1.15 \pm 0.8$ & $0.02 \pm 0.01$ \\
\hline Jumbo & $<\mathrm{MDA}$ & $<\mathrm{MDA}$ & $0.15 \pm 0.1$ & $0.30 \pm 0.1$ & $0.54 \pm 0.2$ & $0.35 \pm 0.1$ & $<\mathrm{MDA}$ & $1.37 \pm 0.8$ & $<\mathrm{MDA}$ \\
\hline Napa Valley & $<\mathrm{MDA}$ & $<\mathrm{MDA}$ & $0.26 \pm 0.1$ & $0.31 \pm 0.1$ & $0.23 \pm 0.1$ & $0.19 \pm 0.1$ & $<\mathrm{MDA}$ & $1.52 \pm 0.9$ & $0.04 \pm 0.01$ \\
\hline Onga & $0.18 \pm 0.1$ & $0.14 \pm 0.1$ & $0.44 \pm 0.1$ & $0.43 \pm 0.2$ & $0.39 \pm 0.1$ & $0.52 \pm 0.2$ & $<\mathrm{MDA}$ & $1.04 \pm 0.5$ & $0.02 \pm 0.01$ \\
\hline Rocyo & $0.21 \pm 0.1$ & $0.22 \pm 0.1$ & $0.23 \pm 0.1$ & $0.45 \pm 0.2$ & $0.65 \pm 0.3$ & $0.45 \pm 0.2$ & $<\mathrm{MDA}$ & $1.72 \pm 0.7$ & $<\mathrm{MDA}$ \\
\hline Mimido & $<\mathrm{MDA}$ & $<\mathrm{MDA}$ & $0.28 \pm 0.1$ & $0.47 \pm 0.2$ & $0.45 \pm 0.2$ & $0.42 \pm 0.1$ & $<\mathrm{MDA}$ & $0.96 \pm 0.4$ & $<\mathrm{MDA}$ \\
\hline Curry Powder & $<\mathrm{MDA}$ & $<\mathrm{MDA}$ & $0.22 \pm 0.1$ & $0.46 \pm 0.2$ & $0.67 \pm 0.3$ & $0.43 \pm 0.1$ & $<\mathrm{MDA}$ & $1.25 \pm 0.5$ & $<\mathrm{MDA}$ \\
\hline
\end{tabular}

where; $A_{s}$, is the average activity concentration of radionuclides $\left(\mathrm{Bqkg}^{-1}\right)$, Is, is the annual intake of spices $\left(\mathrm{kgy}^{-1}\right), \mathrm{DCF}$, is the dose conversion factors $\left(\mathrm{SvBq}^{-1}\right)[11]$.

The dose coefficients were $2.8 \times 10^{-7} \mathrm{SvBq}^{-1}$ for ${ }^{226} \mathrm{Ra}, 6.7 \times 10^{-7}$ $\mathrm{SvBq}^{-1}$ for ${ }^{232} \mathrm{Th}$ and $1.3 \times 10^{-8} \mathrm{SvBq}^{-1}$ for ${ }^{137} \mathrm{Cs}$ [12]. The Consumption rate was defined using food balance sheet [13]. The annual consumption rate was calculated to be $5.70 \mathrm{~kg} /$ year.

Internal doses due to ${ }^{40} \mathrm{~K}$ are not recommended to be taken into consideration towards the total internal dose received. This is because the total amount of potassium in the human body is maintained constant at a fixed body mass. The specific activity of ${ }^{40} \mathrm{~K}$ in potassium in spices is not different from that in food or in the human body. Intake of additional potassium in spices simply results in a reduction in the biological half-life of potassium in the body and no increase in the dose from ${ }^{40} \mathrm{~K}[11]$.

The annual effective dose due to each radionuclide is shown in Table 4. The annual effective dose for the adult population of Accra metropolis due to consumption of the natural spices was estimated to be $1.29 \mu \mathrm{Sv} /$ year of ${ }^{226} \mathrm{Ra}$ and $3.74 \mu \mathrm{Sv} /$ year of ${ }^{232} \mathrm{Th}$. Among the processed spices, the annual effective doses of ${ }^{226} \mathrm{Ra}$ and ${ }^{232} \mathrm{Th}$ were 1.02 and $1.15 \mu \mathrm{Sv} /$ year respectively. The estimated annual effective doses of ${ }^{137} \mathrm{Cs}$ for the natural and processed spices were 0.82 and $0.45 \mu \mathrm{Sv} /$ year respectively with a total value of $1.27 \mu \mathrm{Sv}$ /year.

As seen in Table 4, the effective dose from the radionuclides due to consumption of natural spices contributed the highest to the mean annual effective dose compared to the processed ones. The estimated total annual effective dose received from ${ }^{226} \mathrm{Ra},{ }^{232} \mathrm{Th}$

Table 4: Annual effective dose due to consumption of spices by the inhabitants of Madina in Accra Metropolis, Ghana

\begin{tabular}{|l|c|c|}
\hline \multirow{2}{*}{ Radionuclide } & \multicolumn{2}{|c|}{ Annual effective dose $(\mu \mathrm{Sv} /$ year $)$} \\
\cline { 2 - 3 } & Natural spices & Processed spices \\
\hline${ }^{226} \mathbf{R a}$ & 1.29 & 1.02 \\
\hline${ }^{232} \mathbf{T h}$ & 3.74 & 1.15 \\
\hline Sub-Total & \multicolumn{2}{|c|}{$\mathbf{7 . 2 0}$} \\
\hline${ }^{137}$ Cs & 0.82 & 0.45 \\
\hline Sub-Total & \multicolumn{2}{|c|}{$\mathbf{1 . 2 7}$} \\
\hline Grad Total & \multicolumn{2}{|c|}{$\mathbf{8 . 4 7}$} \\
\hline
\end{tabular}

and ${ }^{137} \mathrm{Cs}$, due to consumption of natural (fresh) and processed spices by the inhabitants of Madina in the Accra metropolis was $8.47 \mu \mathrm{Sv}_{\mathrm{V}}$ /year. Comparing the value from this study with published data for ingestion of natural radionuclides from UNSCEAR (2000) report ( $0.29 \mathrm{mSv}$ /year), it would be seen that the value obtained from this study is far lower than that given in the UNSCEAR report. This shows that consumption of the spices does not pose any significant radiological risk to the general public.

\section{Conclusion}

A systematic study was conducted to evaluate the concentration of radionuclides ${ }^{226} \mathrm{Ra},{ }^{232} \mathrm{Th},{ }^{40} \mathrm{~K}$ and ${ }^{137} \mathrm{Cs}$, in some common spices consumed by inhabitants in the Greater Accra region of Ghana. The average activity concentration of ${ }^{226} \mathrm{Ra},{ }^{232} \mathrm{Th},{ }^{40} \mathrm{~K}$ and ${ }^{137} \mathrm{Cs}$ in the natural spices was found to be higher than the processed ones. The levels of ${ }^{137} \mathrm{Cs}$ observed in the samples were below the exemption levels in any material. The calculated total annual effective dose received from ${ }^{226} \mathrm{Ra},{ }^{232} \mathrm{Th}$ and ${ }^{137} \mathrm{Cs}$ in this study was far lower than the total exposure per person resulting 
from the ingestion of terrestrial radionuclides. The results from the study could be used as baseline values for the Regulatory Authorities to control the exposure of the public to natural and artificial radionuclides due to the consumption of spices in Ghana.

\section{Acknowledgment}

The authors are grateful to the Radiation Protection Institute (RPI) of the Ghana Atomic Energy Commission for making their laboratories available for this research work.

\section{References}

[1]. Ajayi, I.R., Ajayi, O.S. and Fusuyi, A.S. (1995) The Natural Radioactivity of Surface Soils in Ijero - Ekiti, Nigeria, Nig. Jour. of Phy. Vol. 7, pp $101-103$

[2]. Adamson, M. W. (2004) Food in Medieval Times. ISBN 0-313-32147-7

[3]. GSS. (2012) Population and Housing Census, Summary report of final results, Accra, Ghana: Ghana Statistical Service.

[4]. "Accra Metropolitan Assembly (AMA)". http:// ama.ghanadistrict.gov.gh
[5]. "Boundary and Administrative Area". http:// ghanadistricts.com. Retrieved 2010-07-22

[6]. Gilmore G., Hemingway J. D. (1995) Practical Gamma Spectrometry. NY: John Wiley and Sons

[7]. Oresengun M. O, Decker K. M, Sanderson C. G. (1993) Determination of self absorption correction by computation in routine gamma-ray spectrometry for typical environmental samples. J Radioact Radiochem; 4:38-45.

[8]. International Atomic Energy Agency (1996) International Basic Safety Standards for Protection against Ionising Radiation and for the Safety of Radiation Sources. Safety Series No.115, IAEA, Vienna

[9]. ICRP (1999) Protection of the public in situations of prolonged radiation exposure. ICRP Publication 82, Oxford: Pergamon Press

[10]. FAO/WHO (2001) Food Additives and Contaminations, Joint FAO/WHO Food Standards Programme. ALINORM01/12A. P.289

[11]. UNSCEAR (2000) Sources and effects of ionizing radiation. United Nations Scientific Committee on the Effects of Atomic Radiation, United Nations, New York.

[12]. International Commission of Radiological Protection (1994) Dose coefficients for intakes of radionuclides by workers, ICRP publication 68, Oxford: Pergamon Press.

[13]. FAO (2000) Food Balance Sheets, Food and Agriculture Organization of the United Nations 